\title{
Stimulation of Chlamydospore Germination of Fusarium oxysporum f. sp. raphani by Volatile Metabolites produced by Mycelium
}

\author{
HIROSHI OKAZAKI* \\ 岡崎 博*：Fusarium oxysporum f. sp. raphani 菌系の産生する揮発性代謝物の \\ 厚膜胞子に対する発芽促進作用について
}

\begin{abstract}
The mycelium of Fusarium oxysporum f. sp. raphani produces two types of biologically active-volatile metabolites. The one, inhibitory to the chlamydospore germination, is produced under the lack of available carbon sources. The other metabolites, which counteract the activity of the former, were produced under the presence of 30$100 \mathrm{mM}$ of glucose, and these were identified to be ethanol and acetaldehyde by gas chromatography. The inhibition of chlamydospore germination was also counteracted when chlamydospore suspension was exposed to the gas which was released from 0.1 $\mathrm{mM}$ ethanol solution, or $10 \mathrm{mM}$ acetaldehyde solution. The concentration of ethanol produced by glucose-supplied mycelium was enough to counteract the inhibition, but that of acetaldehyde was insufficient. The volatile metabolites produced by glucosesupplied mycelium, ethanol and acetaldehyde, also counteracted the inhibition caused by a volatile inhibitor from soil. The possible mechanism of regulation of chlamydospore germination by parent mycelium is discussed.
\end{abstract}

(Received December 22, 1975)

\section{Introduction}

Various fungi including Fusarium spp. have been reported to produce biologically active volatile metabolites ${ }^{5,6)}$. In previous paper ${ }^{8)}$, it was suggested that an isolate of Fusarium oxysporum f. sp. raphani produced two types of volatile metabolites from mycelium, one inhibitory and the other stimulative for chlamydospore germination of the fungus. Production of these metabolites seemed to depend on the concentration of available carbon sources for the fungus. In this paper, production of ethanol and acetaldehyde by the mycelium of $F$. oxysporum f. sp. raphani in glucose aqueous solutions was demonstrated, and both metabolites, especially ethanol, were found to significantly stimulate chlamydospore germination of the fungus. A preliminary investigation has been reported ${ }^{9}$.

\section{Materials and Methods}

Organism. An isolate of Fusarium oxysporum (Schl.) f. sp. raphani Kend. et Snyd. was used.

Soil and Reagent. A topsoil was taken immediately before use from the field of National Institute of Agricultural Sciences, Nishigahara, Tokyo. The soil sample

* National Institute of Agricultural Sciences, Tokyo, Japan. 農業技術研究所 
passed through a $2 \mathrm{~mm}$ sieve contained 27 to $30 \%$ moisture.

Analytical grade reagents except acetaldehyde were used without further purification. Acetaldehyde was purified by distillation, and the distillate with one-tenth volume of distilled water was stored in a refrigerator until use. Concentration of acetaldehyde in the stock solution was determined by a modified iodometric bisulfite $\operatorname{method}^{1)}$.

Media. The compositions of a basal medium ( $\mathrm{BM}$ ) are as follows: $\mathrm{KCl}, 43 \mathrm{mg}$; $\mathrm{CaCl}_{2} \cdot 2 \mathrm{H}_{2} \mathrm{O}, 92 \mathrm{mg} ; \mathrm{Na}_{2} \mathrm{HPO}_{4} \cdot 12 \mathrm{H}_{2} \mathrm{O}, 179 \mathrm{mg} ; \mathrm{MgSO}_{4} \cdot 7 \mathrm{H}_{2} \mathrm{O}, 123 \mathrm{mg} ; \mathrm{FeCl}_{3} \cdot 6 \mathrm{H}_{2} \mathrm{O}$, $270 \mathrm{mg} ; \mathrm{MnCl}_{2} \cdot 4 \mathrm{H}_{2} \mathrm{O}$, 1mg; $\mathrm{CuSO}_{4} \cdot 5 \mathrm{H}_{2} \mathrm{O}, 1 \mathrm{mg} ; \mathrm{ZnSO}_{4} \cdot 7 \mathrm{H}_{2} \mathrm{O}, 1 \mathrm{mg} ; \mathrm{NH}_{4} \mathrm{Cl}, 107 \mathrm{mg} ;$ distilled water, 1 liter. The $\mathrm{BM}$ adjusted to $\mathrm{pH}$ 5.3-6.0 after autoclaving was used for chlamydospore formation. The supernatant fraction (BMS) of the BM was prepared by centrifuging the $\mathrm{BM}$ and readjusting to $\mathrm{pH} 6.5$, and was used for germination test.

Preparation of mycelial suspension. The mycelial mats obtained from the static cultures in potato glucose broth at $28 \mathrm{C}$ for 7 days were homogenized in sterilized distilled water with a Waring Blendor and the mycelia were washed three times with sterilized water repeating centrifugation. To reduce endogenous reserves, the washed mycelia were resuspended in water and incubated at $28 \mathrm{C}$ for $5 \mathrm{hr}$ with shaking. The starved mycelia were collected, washed once with water by centrifugation, and suspended again in water. The suspension was adjusted to 4-5 mg mycelial dry weight $/ \mathrm{ml}$.

Preparation of chlamydospore. The mycelial suspension without starvation was added to $\mathrm{BM}$ and incubated at $28 \mathrm{C}$. The chlamydospores were harvested after 15 days and cleaned by sonication, filtration, and washing with sterilized $0.1 \mathrm{M}$ phosphate buffer $(\mathrm{pH} \mathrm{6.0})^{8}$. The washed chlamydospores were suspended in small volume of BMS. For the germination test, the suspension was diluted to give 0.8$1.0 \times 10^{4}$ chlamydospores $/ \mathrm{ml}$ of BMS.

Determination of biological activity of volatile substances. Volatile substances were tested for their effects on chlamydospore germination by measuring their counteractive activity against inhibition by volatile inhibitors from mycelium or soil. The assay was conducted using an apparatus as shown in Fig. 1: $0.15 \mathrm{ml}$ of

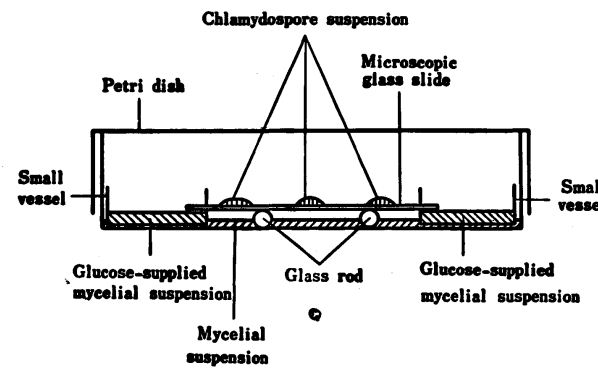

Fig. 1. Apparatus used to determine the effect of volatile metabolites produced by glucose-supplied mycelial suspension on chlamydospore germination.

Refer to text for detailed explanation. the chlamydospore suspension were placed in three places on a glass slide coated with collodion membrane. Two sheets of the slide were horizontally supported on a bent glass rod $(7 \mathrm{~mm}$ in diameter) placed in a $150 \mathrm{~mm}$ petri dish with two small vessels $(40 \mathrm{~mm}$ in diameter and $15 \mathrm{~mm}$ in height). The petri dish received $15 \mathrm{ml}$ of mycelial suspension at the bottom together with $7.5 \mathrm{ml}$ each of glucose-supplied mycelial suspension in two vessels. After $15 \mathrm{hr}$ of incubation at $28 \mathrm{C}$, a drop of $0.1 \% \mathrm{HgCl}_{2}$ was added to the chlamydospore suspension to stop germination. In some experiments, $100 \mathrm{~g}$ of soil were substituted for the mycelial suspension. The glass slides with three drops of chlamydospore suspension were placed on a bent glass rod laid on soil surface and $7.5 \mathrm{ml}$ of the glucose-supplied mycelial suspension were poured into each of two small vessels placed in the petri dish. To determine the counteractive activity, $1.0 \mu \mathrm{M}-1.0 \mathrm{M}$ ethanol or acetaldehyde solution was substituted for the glucose-supplied mycelial suspension. A petri dish with $15 \mathrm{ml}$ of water served as control. Percentage of chlamydospore germination was calculated 
after microscopic observation of 6 drops on two slides, 100 chlamydospores/drop. Care was taken to separate all these suspensions throughout the experiments.

Analysis of ethanol and acetaldehyde. Ethanol and acetaldehyde were analyzed by gas chromatography. Germination tests were conducted in a petri dish installed with a small silicone gum stopper at the center of the lid. After $15 \mathrm{hr}$ of incubation at $28 \mathrm{C}, 1-2 \mathrm{ml}$ of air and $0.1-3.0 \mu \mathrm{l}$ of chlamydospore suspensions in the petri dish were withdrawn by a syringe for the analysis of ethanol and acetaldehyde. The collected samples were analyzed by gas chromatography using a Shimadzu Model $5 \mathrm{AF}$ equipped with a flame ionization detector. The constituents of the samples were identified by comparing retention times with those of authentic ethanol, and acetaldehyde on three different columns. The concentrations of ethanol and acetaldehyde in samples were determined on the basis of the standard calibration curves which were made using a column B with a direct injection of known concentrations of ethanol, or acetaldehyde aqueous solution, respectively. Operating conditions are as follows: Column A was packed with $15 \%$ Ethofat $60 / 25^{\circledR}$ on $60-80$ mesh, acid washed Chromosorb $\mathrm{W}$ and it was operated at $40 \mathrm{C}$ with an injection temperature of 100 C. Column B and C were packed with $80-100$ mesh Porapak $\mathrm{S}^{\circledR}$, and with 60-80 mesh Chromosorb 105 ${ }^{\circledR}$, respectively. Both column B, and C were operated at $150 \mathrm{C}$ with an injection temperature of $150 \mathrm{C}$. Each column was composed of glass (1.0 $\mathrm{m}$ long, $3 \mathrm{~mm}$ inner diameter). The flow rate of carrier gas (nitrogen) was adjusted at $50 \mathrm{ml} / \mathrm{min}$.

Deionized distilled water was always used throughout the experiments. The experiment was repeated more than three times.

\section{Results}

\section{Volatile germination stimulators}

In previous paper ${ }^{8)}$, the author assumed that the mycelium of $F$. oxysporum $f$. sp. raphani might produce volatile metabolites stimulative for its own chlamydospore germination in the presence of glucose.

The biological activity of the metabolites was further investigated using the

Table 1. Effect of volatile metabolites produced by glucose-supplied mycelium on the inhibition of chlamydospore germination by volatile inhibitors from mycelium or soil

\begin{tabular}{l|c|c|c}
\hline \hline \multicolumn{1}{c|}{$\begin{array}{c}\text { Material in } \\
\text { petri dish a) }\end{array}$} & $\begin{array}{c}\text { Material in } \\
\text { small vessels b) }\end{array}$ & Mean & Standard error \\
\hline Water & - & 94.7 & 1.2 \\
Mycelial suspension & \multicolumn{1}{c}{$\begin{array}{c}\text { Water } \\
\text { Mycelial suspension }\end{array}$} & $\begin{array}{c}\text { Mycelial suspension } \\
\text { glucose d) } \\
\text { Soil }\end{array}$ & 25.3 \\
Soil & $\begin{array}{c}\text { Wycelial suspension } \\
\text { glucose d) }\end{array}$ & 97.9 & 0.5 \\
\hline
\end{tabular}

a) The petri dish contained $15 \mathrm{ml}$ of water, mycelial suspension, or $100 \mathrm{~g}$ of soil at the bottom (Refer to Fig. 1).

b) Each of two vessels contained $7.5 \mathrm{ml}$ of water, or glucose-supplied mycelial suspension.

c) Germination rate was determined on the basis of a count of 100 chlamydospores/drop in each of 6 drops placed on two glass slides.

d) Final concentration of glucose was $30 \mathrm{mM}$. 
apparatus as shown in Fig. 1. Whether or not the inhibition caused by volatile inhibitors from mycelium or soil is counteracted by these metabolites was examined. The results are shown in Table 1 . The germination was significantly inhibited when mycelial suspension or soil was placed at the bottom of the petri dish, while the inhibition was counteracted when glucose-supplied mycelial suspensions were placed in the small vessels in the petri dish. There were no direct contacts among chlamydospore suspension, glucose-supplied mycelial suspension, and mycelial suspension or soil. These results indicate that mycelium produces volatile metabolites stimulative for chlamydospore germination in the presence of glucose.

\section{Identification of volatile metabolites}

Two peaks were detected on the gas chromatogram when the air of the petri dish with glucose-supplied mycelial suspension was analyzed by gas chromatography. These two peaks showed the same retention times as those of ethanol and acetaldehyde, respectively. Further confirmation was made by using three different columns (Ethofat $60 / 25^{\circledR}$, Porapak $\mathrm{S}^{\circledR}$, and Chromosorb $105^{\circledR}$ ). There was no detectable change in the shape of peak, but the peak height was increased when a mixture of the air and the vapor of authentic ethanol or acetaldehyde was analyzed on these columns. Table 2 shows the concentrations of ethanol and acetaldehyde in the air

Table 2. Effect of glucose on the production of ethanol and acetaldehyde by mycelia as estimated by the contents of these metabolites in the air inside the petri dishes and in chlamydospore suspensions ${ }^{a}$

\begin{tabular}{|c|c|c|c|c|}
\hline \multirow{2}{*}{$\begin{array}{l}\text { Glucose concentration } \\
\text { in } \\
\text { mycelial suspension } \\
(\mathrm{mM})\end{array}$} & \multicolumn{2}{|c|}{ Ethanol } & \multicolumn{2}{|c|}{ Acetaldehyde } \\
\hline & $\underset{(\mu \mathrm{g} / \mathrm{ml})}{\operatorname{Air}}$ & $\begin{array}{l}\text { Chlamydospore } \\
\text { suspension }(\mu \mathrm{g} / \mathrm{ml})\end{array}$ & $\underset{(\mu \mathrm{g} / \mathrm{ml})}{\operatorname{Air}}$ & $\begin{array}{c}\text { Chlamydospore } \\
\text { suspension }(\mu \mathrm{g} / \mathrm{ml})\end{array}$ \\
\hline 0 b) & Not detected & Not detected & Not detected & Not detected \\
\hline 30 & 0.016 & 83 & 0.002 & Not detected \\
\hline 50 & 0.030 & 230 & 0.009 & Not detected \\
\hline 100 & 0.11 & 570 & 0.04 & 9 \\
\hline
\end{tabular}

a) Components analyzed were collected from the apparatus as shown in Fig. 1: The petri dish contained $15 \mathrm{ml}$ of mycelial suspension at the bottom and each of two vessels contained $7.5 \mathrm{ml}$ of glucose-supplied mycelial suspension. After $15 \mathrm{hr}$ of incubation at $28 \mathrm{C}$, concentrations of ethanol and acetaldehyde were determined.

b) Each of two vessels contained $7.5 \mathrm{ml}$ of water.

of the petri dishes and in chlamydospore suspensions. Neither ethanol nor acetaldehyde was detected both in the air and in the chlamydospore suspensions in the absence of glucose-supplied mycelial suspension. While, both ethanol and acetaldehyde were detected in the air at the concentrations of $0.016-0.11 \mu \mathrm{g} / \mathrm{ml}$ and $0.002-0.04$ $\mu \mathrm{g} / \mathrm{ml}$, respectively, in the presence of glucose-supplied mycelial suspensions in the vessels. Ethanol was also detected in the chlamydospore suspension at the concentrations of $83-570 \mu \mathrm{g} / \mathrm{ml}(1.8-12 \mathrm{mM})$, but concentration of acetaldehyde detected in the suspension was $9 \mu \mathrm{g} / \mathrm{ml}(0.2 \mathrm{mM})$ when the concentration of glucose in the mycelial suspension was adjusted to $100 \mathrm{mM}$. The amounts of ethanol and acetaldehyde increased as concentration of glucose in the mycelial suspension was increased. However, the concentrations of these metabolites in the air after $15 \mathrm{hr}$ of incubation were decreased when the amount of mycelia in the suspension was increased from 
$5.0 \mathrm{mg}$ dry weight/ml to $10 \mathrm{mg}$ dry weight $/ \mathrm{ml}$. Therefore, the concentration of metabolites seems to change depending on concentrations of glucose and the amount of mycelia in the suspension.

\section{Activity of ethanol and acetaldehyde for chlamydospore germination}

Stimulative effect of ethanol was examined by measuring the degree of counteraction of the inhibition by a volatile inhibitor from mycelium (Table 3). About $93 \%$ chlamydospore germination occurred in control. The germination rate decreased to $56.1 \%$ when water was substituted for mycelial suspension. The inhibition was counteracted by the gas released from $0.1-100 \mathrm{mM}$ ethanol placed in the small vessels. The germination was inhibited to a certain extent when concentration of ethanol was increased up to $1000 \mathrm{mM}$.

Table 3. Effect of ethanol on chlamydospore germination under the influence of a volatile inhibitor from mycelium a)

\begin{tabular}{c|c|c}
\hline \multirow{2}{*}{$\begin{array}{c}\text { Ethanol } \\
\text { concentration } \\
\text { (mM) }\end{array}$} & \multicolumn{2}{|c}{ germination } \\
\cline { 2 - 3 } Control b) & Mean & Standard error \\
$0^{\mathrm{c})}$ & 92.8 & 1.3 \\
1000 & 56.1 & 8.8 \\
100 & $63.8 \mathrm{~d})$ & 14.3 \\
10 & 93.2 & 2.3 \\
1 & 93.4 & 1.9 \\
0.1 & 94.1 & 0.9 \\
0.01 & 89.1 & 1.1 \\
0.001 & 61.1 & 4.5 \\
\end{tabular}

a) The petri dish contained $15 \mathrm{ml}$ of mycelial suspension at the bottom and each of two vessels contained $7.5 \mathrm{ml}$ of ethanol solutions (Refer to Fig. 1).

b) Fifteen $\mathrm{ml}$ of water at the bottom of a petri dish.

c) Each of two vessels contained $7.5 \mathrm{ml}$ of water.

d) Lengths of germ-tube were two to five times of the diameter of chlamydospore without further growth.

Table 4. Effect of acetaldehyde on chlamydospore germination under the influence of a volatile inhibitor from mycelium a)

\begin{tabular}{c|c|c}
\hline \hline \multirow{2}{*}{$\begin{array}{c}\text { Acetaldehyde } \\
\text { concentration } \\
(\mathrm{mM})\end{array}$} & \multicolumn{2}{|c}{$\%$ germination } \\
\cline { 2 - 3 } & Mean & Standard error \\
\hline Control b) $^{\mathrm{b})}$ & 95.6 & 1.4 \\
100 & 54.9 & 8.0 \\
10 & 0 & - \\
1 & 95.3 & 1.0 \\
0.1 & 66.8 & 7.0 \\
0.01 & 45.1 & 6.7 \\
0.001 & 49.1 & 6.1 \\
\hline
\end{tabular}

a) The petri dish contained $15 \mathrm{ml}$ of mycelial suspension at the bottom and each of two vessels contained $7.5 \mathrm{ml}$ of acetaldehyde solutions (Refer to Fig. 1).

b) Fifteen $\mathrm{ml}$ of water at the bottom of a petri dish.

c) Each of two vessels contained $7.5 \mathrm{ml}$ of water. 
The inhibition caused by the volatile inhibitor was also counteracted by the gas released from $10 \mathrm{mM}$ acetaldehyde placed in the small vessels and the germination was completely inhibited at $100 \mathrm{mM}$ (Table 4).

The inhibition by a volatile inhibitor from soil was also counteracted by the gas released from $0.1 \mathrm{mM}$ ethanol, or $10 \mathrm{mM}$ acetaldehyde (Table 5).

Table 5. Effects of ethanol and acetaldehyde on chlamydospore germination under the influence of a volatile inhibitor from soil a)

\begin{tabular}{c|c|c}
\hline \multicolumn{1}{c|}{$\begin{array}{c}\text { Concentration } \\
(\mathrm{mM})\end{array}$} & Mean & Sermination \\
\cline { 2 - 3 } & 94.7 & 2.0 \\
Control b) $^{\text {c) }}$ & 34.6 & 6.5 \\
10 (ethanol) & 97.2 & 2.2 \\
1 (ethanol) & 96.0 & 2.2 \\
0.1 (ethanol) & 79.1 & 6.9 \\
0.01 (ethanol) & 40.9 & 3.1 \\
10 (acetaldehyde) & 91.7 & 1.9 \\
1 (acetaldehyde) & 48.2 & 4.7 \\
0.1 (acetaldehyde) & 43.5 & 3.6 \\
\hline
\end{tabular}

a) The petri dish contained $100 \mathrm{~g}$ of soil at the bottom and each of two vessels contained $7.5 \mathrm{ml}$ of solutions of ethanol or acetaldehyde (Refer to Fig. 1).

b) Fifteen $\mathrm{ml}$ of water at the bottom of a petri dish.

c) Each of two vessels contained $7.5 \mathrm{ml}$ of water.

\section{Discussion}

Carlile et al. observed that inhibitory effect of mycelium on spore germination of Botrytis cinerea increased with the age of parent mycelium ${ }^{2)}$. The inhibitory effect of mycelium of $F$. oxysporum $\mathrm{f}$. sp. raphani on its own chlamydospore germination was inversely related with the available carbon sources added to the mycelium ${ }^{8)}$.

The data presented in this paper clearly showed that the mycelium of $F$. oxysporum f. sp. raphani produced volatile metabolites stimulative for chlamydospore germination in glucose solutions (Table 1). These metabolites were identified as ethanol and acetaldehyde. The concentrations of ethanol produced were enough to counteract the inhibition by volatile inhibitors from mycelium or soil (Table $2,3,5$ ), while those of acetaldehyde were insufficient (Table 2, 4, 5). Therefore, among the volatile metabolites produced by mycelium in the presence of glucose, ethanol is most likely the major counteractant of the inhibition.

Little is known about the effect of ethanol on spore germination, although formation of ethanol was rather common among fungi, including Fusarium spp. ${ }^{3}$ ) Cochrane et al. reported that macroconidia of Fusarium solani f. sp. phaseoli required for germination a factor in yeast extract, which could be replaced by ethanol4). Weinhold et al. showed that ethanol stimulated mycelial growth and rhizomorph formation of Armillaria mellea ${ }^{11)}$. It was previously reported that the inhibition of chlamydospore germination of $F$. oxysporum f. sp. raphani due to high concentration of chlamydospores was counteracted by adding glucose to the chlamydospore suspension at the concentrations of 1-10 $\mathrm{mM}^{8)}$. However, data in this work clearly showed that ethanol is more effective than glucose as a stimulator.

Conflicting results have been reported about the activity of acetaldehyde on 
fungi. Robinson et al. demonstrated the presence of ethanol and acetaldehyde in volatile metabolites from cultures of $F$. oxysporum, and considered that acetaldehyde was a main factor responsible for sporostasis ${ }^{10)}$. On the other hand, Linderman et al. reported that acetaldehyde stimulated germination and growth of sclerotia of Sclerotium rolfsii ${ }^{7)}$. These discrepancies may result from the differences in experimental conditions such as concentrations of acetaldehyde, species of fungi tested, and so on. The present investigation showed that acetaldehyde acted on chlamydospores as stimulator or inhibitor, depending on its concentration (Table 4). Furthermore, the fact that concentration of acetaldehyde produced by parent mycelium was insufficient to inhibit chlamydospore germination may present further evidence for the production of an unknown volatile inhibitor by mycelium in conditions lacking available carbon sources.

The mycelium of $F$. oxysporum f. sp. raphani produced ethanol in the presence of glucose, which stimulates the germination of chlamydospores, but in the absence of available carbon sources the mycelium seems to produce a different type of volatile metabolite which inhibits the germination of chlamydospores. Whether the production of the inhibitor depends on the concentrations of available carbon sources has not yet been determined.

In conclusion, germination of chlamydospres of $F$. oxysporum f. sp. raphani is controlled by two types of volatile metabolites, one stimulative for germination, and the other inhibitory. Production and/or activity of these metabolites are most likely controlled by the concentration of available carbon sources in the medium.

The author is grateful to Dr. Tsuneo Watanabe, National Institute of Agricultural Sciences, for his help in preparation of the manuscript.

\section{Literature cited}

1) Arighi, A. L., Joslyn, M. A. and Marsh, G. L. (1936). Ind. Eng. Chem. 28: 595-598.

2) Carlile, M. J. and Sellin, M. A. (1963). Trans. Br. mycol. Soc. 46: 15-18.

3) Cochrane, V. W. (1958). Physiology of Fungi, John Wiley \& Sons, New York, pp. 214.

4) Cochrane, J. C., Cochrane, V. W., Simon, F. G. and Spaeth, J. (1963). Phytopathology 53: 1155-1160.

5) Fries, N. (1973). Trans. Br. mycol. Soc. 60: 1-21.

6) Hutchinson, S. A. (1973). Ann. Rev. Phytopathology 11: 223-246.

7) Linderman, R. G. and Gilbert, R. G. (1969). Phytopathology 59: 1366-1372.

8) Okazaki, H. (1975). Ann. Phytopath. Soc. Japan 41: 314-320.

9) Okazaki, H. (1975). Ibid. 41.270 (abstr.).

10) Robinson, P. M. and Park, D. (1966). Trans. Br. mycol. Soc. 49: 639-649.

11) Weinhold, A. R. and Garraway, M. O. (1966). Phytopathology 56: 108-112.

和 文 摘 要

Fusarium oxysporum f. sp. raphani 菌糸の産生する揮

発性代謝物の厚膜胞子に対する発芽促進作用について

岡 崎博

Fusarium oxysporum f. sp. raphani の菌系がグルコース水溶液中で産生する揮発性代謝物およびそれ 
の厚膜胞子の発芽に対する作用について検討した。菌系または土壌の放出する 揮発性物質によって起きる厚 膜胞子の発芽阻害は，30～100mM のグルコースを添加した菌糸懸濁液を入れたペトリ皿の気相に抏いて打ち 消された。この気相をガスクロマトグラフィーで分析した結果，エチルアルコールが $0.016 〜 0.11 \mu \mathrm{g} / \mathrm{ml}$, ア セトアルデヒドが $0.002 \sim 0.04 \mu \mathrm{g} / \mathrm{ml}$ 検出された。さらに，乙の気相においた厚膜胞子懸濁液からはエチル アルコールが 83〜 $570 \mu \mathrm{g} / \mathrm{ml}(1.8 \sim 12 \mathrm{mM})$ ，アセトアルデヒドが $0 \sim 9 \mu \mathrm{g} / \mathrm{ml}(0 \sim 0.2 \mathrm{mM})$ 検出された。この 二つの代謝物について厚膜胞子の発芽に対する作用を調べた結果，菌系または土壌による厚膜胞子の発芽阻 害は, $0.1 \mathrm{mM}$ のチルアルコールまたは $10 \mathrm{mM}$ のアセトアルデヒドを入れたペトリ皿の気相において打ち消 された。グルコースの存在下で菌糸が産生する揮発性代謝物のうち，エチルアルコールはこの発芽阻害を打 ち消すのに必要な濃度に達していたが，アセトアルデヒドはそれに達しなかった。したがって，グルコース の存在下で菌系が示す発芽促進作用はこのとき菌糸が産生するエチルアルコールによるものであると結論し た。 